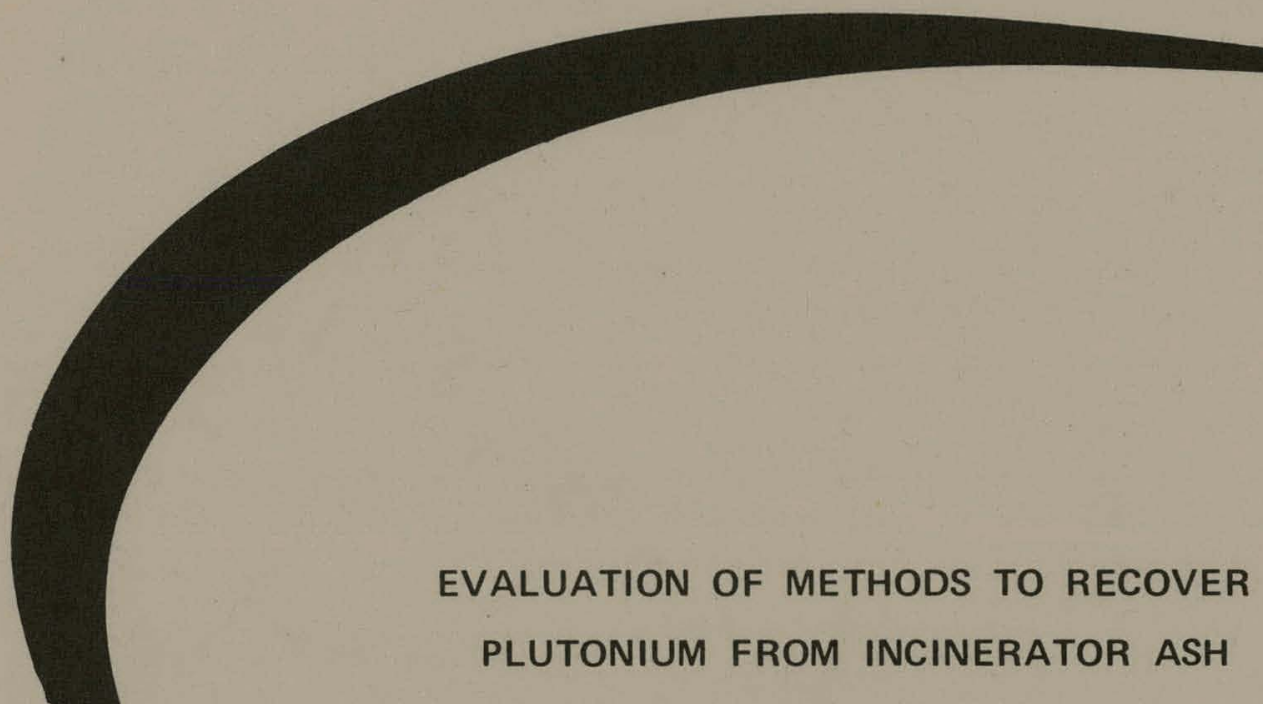

Donald L. Ziegler

John W. Lindsay

John K. Fraser

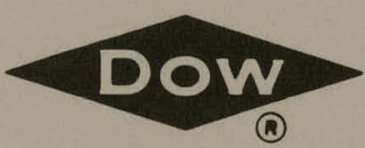

THE DOW CHEMICAL COMPANY

ROCKY FLATS DIVISION

P. O. BOX 888

GOLDEN, COLORADO 80401

U.S. ATOMIC ENERGY COMMISSION

CONTRACT AT(29.1)-1106 


\section{DISCLAIMER}

This report was prepared as an account of work sponsored by an agency of the United States Government. Neither the United States Government nor any agency Thereof, nor any of their employees, makes any warranty, express or implied, or assumes any legal liability or responsibility for the accuracy, completeness, or usefulness of any information, apparatus, product, or process disclosed, or represents that its use would not infringe privately owned rights. Reference herein to any specific commercial product, process, or service by trade name, trademark, manufacturer, or otherwise does not necessarily constitute or imply its endorsement, recommendation, or favoring by the United States Government or any agency thereof. The views and opinions of authors expressed herein do not necessarily state or reflect those of the United States Government or any agency thereof. 


\section{DISCLAIMER}

Portions of this document may be illegible in electronic image products. Images are produced from the best available original document. 


\section{LEGAL NOTICE}

This report was prepared as an account of work sponsored by the United States Government. Neither the United States nor the United States Atomic Energy Commission, nor any of their employees, nor any of their contractors, subcontractors, or their employees, makes any warranty, expressed or implied, or assumes any legal liability or responsibility for the accuracy, completeness or usefulness of any information, apparatus, product or process disclosed, or represents that its use would not infringe privately owned rights.

Printed in the United States of America

Available from the

National Technical Information Service

U. S. Department of Commerce

Springfield, Virginia 22151

Price: Printed Copy $\$ 3.00$; Microfiche $\$ 0.65$ 


\title{
EVALUATION OF METHODS TO RECOVER PLUTONIUM FROM INCINERATOR ASH
}

\author{
Donald L. Ziegler \\ John W. Lindsay \\ John K. Fraser
}

This report was prepared as an account of work sponsored by the United States Government. Neither the United States nor the United States Atomic Energy the United nor any of their employees, nor any of rommission, nor any of their employees, nor any of makes any warranty, express or implied, or assumes any legal liability or responsibility for the accuracy, completeness or usefulness of any information, apparatus, pleteness or usefulness of any information, or process disclosed, or represents that its use would not infringe privately owned rights.

THE DOW CHEMICAL COMPANY ROCKY FLATS DIVISION

P. O. BOX 888

GOLDEN, COLORADO 80401

Prepared under Contract AT(29-1)-1106

for the

Albuquerque Operations Office

U. S. Atomic Energy Commission 
RFP-1723 


\section{CONTENTS}

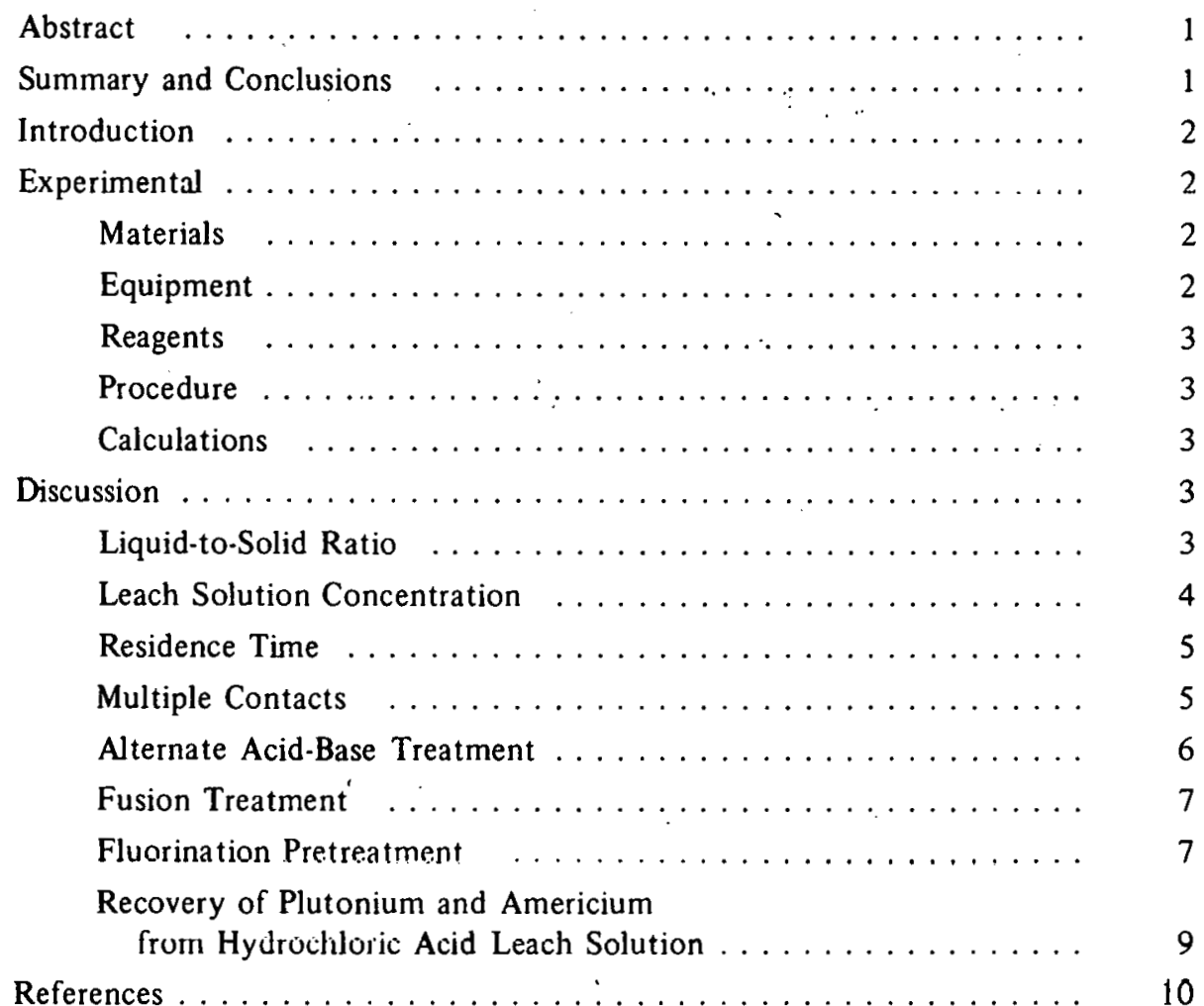


RFP-1723

\section{ACKNOWLEDGMENTS}

The authors thank the Plutonium Analytical Laboratory personnel for their service on the numernus samples generated during this study. We also thank R. Southworth and the personnel in Chemical Operations for supplying the incinerator ash and ash leach heel used in these experiments. 


\title{
EVALUATION OF METHODS TO RECOVER PLUTONIUM FROM INCINERATOR ASH
}

\author{
Donald L. Ziegler, John W. Lindsay, and John K. Fraser
}

\begin{abstract}
Laboratory experiments were performed to evaluate the methods of hydrochloric acid leaching, nitric acid leaching, various fusion-leaching, and fluorinationleaching used for removal of plutonium from incinerator ash and residue from leached incinerator ash. Three precipitation methods were evaluated for removing the plutonium from a hydrochloric acid solution. The results indicate that the hydrochloric leaching of ash, coupled with a lanthanum fluoride-carried precipitation, is superior to other methods tested for recovering plutonium from incinerator ash.
\end{abstract}

\section{SUMMARY AND CONCLUSIONS}

Experiments were performed to find an effective method to recover plutonium from incinerator ash or ash leach heel.* The objective was to produce not only a discardable heel, but a heel which would be a factor of ten below the Rocky Flats economic discard concentration limit for incinerator ash $(0.007 \mathrm{~g} \mathrm{Pu} / \mathrm{g}$ solid). The experiments used hydrochloric acid leaching, nitric acid leaching, alternating caustic and hydrochloric acid leaching, a variety of fusions followed by acid leaching, and fluorination treatment prior to a nitric acid leach of incinerator ash. Fluoride precipitation, oxalate precipitation, and hydroxide precipitation were used to recover the plutonium from a hydrochloric acid leach solution.

Variables evaluated in hydrochloric acid and nitric acid leaching of incinerator ash included the liquid-to-solid ratio evaluated from 2 to $10 \mathrm{ml}$ of leach solution per gram of ash, residence time from 1 to 4 hours, leach solution composition, and multiple contacts with fresh acid. The liquid-to-solid ratio and the residence time were found to have only minor effects on plutonium recovery in the hydrochloric acid system. After two contacts of the ash with fresh hydrochloric acid leach solution, the efficiency per leach became lower. Hydrochloric acid leaching of incinerator ash is an effective plutonium recovery method and, in general, is superior to the nitric acid leach system. About $94 \%$ of the residues produced by a single hydrochloric acid leach were below the present economic discard limit ( $25 \%$ were a factor of ten below), whereas none of the nitric acid leached residues reached the discard limit. The nitric acid leaching of incinerator

\footnotetext{
- Ash leach heel is defined as the undissolved solids remaining when incinerator ash is subjected to a leaching operation.
}

ash is more dependent on liquid-to-solid ratio $(\mathrm{ml} / \mathrm{g})$ than is the hydrochloric acid system.

The optimum hydrochloric acid leaching conditions for incinerator ash are approximately as follows:

1. Leach solution composition: $7.5 M$ hydrochloric acid

$$
\begin{aligned}
& 0.1 \mathrm{M} \mathrm{SnCl}_{2} \\
& 0.5 \mathrm{M} \mathrm{HF}
\end{aligned}
$$

2. Temperature: $\quad$ Reflux conditions

\section{Acid to ash ratio: $\quad 5 \mathrm{ml} / \mathrm{g}$}

4. Residence time: 2 hours

5. Number of contacts with
fresh acid:

Calculations have not been performed to determine the optimum economic conditions for the hydrochloric acid leaching in production equipment. The above conditions could be expected normally to produce a heel at or below the present discard level for incinerator ash.

The plutonium recovered in the hydrochloric acid leaching of incinerator ash can be effectively removed by either a fluoride precipitation or a hydroxide precipitation. The precipitates can then be dissolved in nitric acid and purified in the present production process which utilizes anion exchange, peroxide precipitation, calcination, hydrofluorination, and reduction with calcium to produce plutonium metal. The fluoride precipitation is preferred because it provides greater purification than the hydroxide precipitation method. Briefly, fluoride precipitation consists of adjusting the leach solution to $0.5 \mathrm{~N}$ acid, the addition of hydrofluoric acid to produce a solution about $2 M \mathrm{HF}$, and filtering of the resulting precipitate. This method produces a supernatant solution of about $5 \times 10^{-4}$ g Pu/liter.

Eighteen experiments were performed to evaluate fusions, coupled with a leaching step, but only in two runs was the plutonium recovery equivalent or superior to a simple hydrochloric acid leach.

The experiments performed using alternating caustic and hydrochloric acid leaching of incinerator ash were only slightly better than a simple hydrochloric acid leach. 
Experiments using hydrochloric acid leaching, fluorination and subsequent nitric acid leaching of incinerator ash produced combined plutonium recoveries (for the two acid leaches) above those obtained by a double contact with fresh hydrochloric acid. However, these fluorination experiments are only preliminary and additional experiments will be performed to confirm the results.

\section{INTRODUCTION}

Casting and machining operations at Rocky Flats generate residues or scrap materials which are contaminated with significant quantities of plutonium. These residues include insulation, paper, glovebox gloves, and graphite mold material. In the plutonium recovery area. the residues are processed ${ }^{1}$ to remove the plutonium which is then purified by ion exchange in the nitric acid system. In the ion exchange process, additional residues are generated from degraded ion exchange resin, reduction sand, slag and crucibles, used glassware, used equipment, paper, and glovebux gluves.

All of these residues are subjected to a bulk assay and those which contain sufficient plutonium are processed for recovery. The plutonium discard concentration for each type of residue is determined by comparing the value of the recoverable plutonium to the cost of processing the residue.

Some of the residues are converted to a form suitable for nitric acid processing by utilizing pretreatment processes such as sand blasting metal, scarfing graphite molds, and incineration of paper, plastic, and cloth. The incinerator ash is a particularly difficult residue to process ${ }^{2}$ requiring. as many as 5 or 6 leach contacts before the plutonium level can be reduced to an economical discard concentration.

Because of the present plans to improve management of radioactive waste, it is desirable to decrease both the volume and the radionuclide content of the waste materials. Decreasing the radionuclide content of the waste will decrease the potential hazard associated with the long-term storage of the waste. Decreasing the waste volume will make improved storage methods more practical. Therefore, preliminary objectives have been established to provide methods to decrease the plutonium concentration in Rocky Flats wastes by a factor of ten below the present economic discard limits.

This report covers experiments performed to evaluate the use of hydrochloric acid leaching for recovery of plutonium from incinerator ash. A hydrochloric acid system ${ }^{3,4}$ has been previously investigated for the dissolution of refractory oxides similar to those found in incinerator ash. Experiments using nitric acid leaching solution were also performed to provide a basis for comparison.'

\section{EXPERIMENTAL}

\section{Materials}

The following residues were used in the experiments for evaluating both the hydrochloric acid and nitric acid leaching methods:

1. Incinerator Ash. This residue was the ash produced when combustible material was incinerated. It had not been previously subjected to nitric acid leaching in the Bosky Flats plutnnium rennvery proncess. The lead content of the ash was higher than normal incinerator ash because a large number of leaded glovebox gloves were included in the material fed to the incinerator. Particle sizes of the material was such that grcater than $95 \mathrm{wt} \%$ passed through a 100-Tyler mesh screen. Two large samples of this material were used in the experiments and each sample was analyzed by radioassay for plutonium and americium content prior to use. One sample contained $0.036 \mathrm{~g} \mathrm{Pu} / \mathrm{g}$ solid and $0.000048 \mathrm{~g} \mathrm{Am} / \mathrm{g}$ solid and the other sample contained $0.025 \mathrm{~g} \mathrm{Pu} / \mathrm{g}$ solid and $0.000040 \mathrm{~g} \mathrm{Am} / \mathrm{g}$ solid.

2. No. 5 Ash Leach Heel. This material is incinerator ash that has been leached in the production process five times using a nitric acid-fluoride ion solution. This material contained $0.020 \mathrm{~g} \mathrm{Pu} / \mathrm{g}$ sulid which is above the discard limit ( $0.007 \mathrm{~g} \mathrm{Pi} / \mathrm{g}$ solid) for this type of material. Further nitric acid leaching of this type of material in production equipment usually does not substantially decrease the plutonium concentration.

\section{Equipment}

The leaching part of each experiment was done in a $1000-\mathrm{ml}$ glass boiling flask except for the fusion products which were leached in a $250-\mathrm{ml}$ flask.

A glass condenser was placed over the boiling flask to condense the escaping vapor. Heating and stirring were accomplished by a combination hot plate-stir plate using a Teflon-coated stir bar. Filtering of the leached material was accomplished by the use of a medium porosity glass filter funnel fitted to a suction flask. 


\section{Reagents}

A solution containing $10.0 \mathrm{MHCl}, 0.5 \mathrm{M} \mathrm{SnCl}_{2}$, and $0.1 M \mathrm{HF}$ was used for all of the hydrochloric acid leach tests with the exception of leaches made to determine the optimum concentrations of the leach solution components.

In all leach tests using nitric acid, a solution consisting of $12.5 \mathrm{M} \mathrm{HNO}_{3}$ and $0.2 \mathrm{M} \mathrm{CaF}_{2}$ was used. The calcium fluoride was added separately as the solid.

A solution of $12.5 M \mathrm{HNO}_{3}$ and $0.84 \mathrm{MAl}\left(\mathrm{NO}_{3}\right)_{3} \cdot 9 \mathrm{H}_{2} \mathrm{O}$ was used to leach incinerator ash which had been pretreated by fluorination.

The samples produced from the various fusion experiments were leached in a variety of solutions. Reagents used for the fusions and fusion product leaches are covered in the discussion.

\section{Procedure}

The material to be leached was weighed on a balance to the nearest tenth of a gram and placed in a boiling flask. A known volume and composition of leaching solution was prepared and added to the boiling flask. The resulting mixture was heated and stirred until the slurry was boiling. After a predetermined length of time, 1 to 4 hours, the flask was removed from the hot plate and cooled. The slurry was then filtered through a funnel and the resulting solid was washed carefully with dilute acid. The dried solid was weighed, sampled, and analyzed for plutonium and americium by a fusion, dissolution, and radioassay method.

The filtrate was diluted to a known volume and sampled for a radioassay analysis of the plutonium and americium.

\section{Calculations}

The following calculations were made to obtain a record of the relative effect of each leach:

\section{Calculation 1:}

$\%$ Solid dissolved $=\frac{(\text { weight feed }- \text { weight residue }) \times 100}{\text { weight food }}$

\section{Calculation 2:}

$$
\begin{aligned}
& \% \mathrm{Pu} \text { or } \mathrm{Am} \\
& \text { recovered }
\end{aligned}=\frac{\text { (weight } \mathrm{Pu} \text { or } \mathrm{Am} \text { in solution) } \times 100}{\begin{array}{l}
\text { weight } \mathrm{Pu} \text { or } \mathrm{Am} \\
\text { in solution }
\end{array}}
$$

To obtain a check on the plutonium and americium analysis for the solution and leach heel produced in each experiment, the following material balance calculation was made and the calculated value for plutonium and americium concentration in the feed was compared to the original feed analysis

\section{Calculation 3:}

$\begin{aligned} & \text { \% Pu or Am } \\ & \text { in feed }\end{aligned}=\frac{\left.\begin{array}{l}\text { weight of } \mathrm{Pu} \text { or } \\ \mathrm{Am} \text { in solution }\end{array}+\begin{array}{l}\text { weight of } \mathrm{Pu} \text { or } \\ \mathrm{Am} \text { in residue }\end{array}\right) \times 100}{\text { weight feed }}$

\section{DISCUSSION}

\section{Liquid-To-Solid Ratio}

The effect of varying the liquid-to-solid ratio (milliliter leach solution per gram solid material) on the amount of plutonium and americium removed by leaching in both the hydrochloric acid and nitric acid systems was evaluated. The results of these experiments are presented in Table 1 . In the hydrochloric acid system, increasing the liquid-tosolid ratio from $2: 1$ to $10: 1$ resulted in only a minor improvement in the recovery of plutonium and americium from incinerator ash (Run No. 1 through No. 5). In each of these experiments (Run 1 to 5), the plutonium concentration in the material was reduced to a value below the present discard limit of $0.007 \mathrm{~g} \mathrm{Pu} / \mathrm{g}$. solid.

In the nitric acid system, increasing the liquid-to-solid ratio from 2:1 to 10:1 resulted in an increase from 20.3\% to $76.3 \%$ removal of plutonium from incinerator ash (Runs 6 through 13). However, the plutonium concentration in the material was not reduced to the present discard limit in any of the experiments using the nitric acid leach (Runs 6 through 13). Runs 14 and 15 were hydrochloric acid leaches made using No. 5 ash leach heel. This is incinerator ash which has been leached five times in the production process with nitric acid. Only a small improvement in recoveries was noted when the liquid-to-solid ratio was increased from 2:1 to 5:1. While these runs produced a heel below the present plutonium discard concentration, they were not as low as that obtained with unleached ash in Runs 1 through 5. However, only a 2 -hour contact time was used in the ash heel runs (14 and 15) where a 4-hour contact time was used in the unileáclied ash ıuns (1 thuugh 5 ). 
RFP-1723

Table I. Recovery of Plutonium and Americium from Incinerator Ash. (Effect of liquid-to-solid ratio.)

\begin{tabular}{|c|c|c|c|c|c|c|c|c|}
\hline \multirow[b]{2}{*}{ Run } & \multirow{2}{*}{$\begin{array}{c}\text { Leach } \\
\text { System }^{\mathrm{a}} \\
\end{array}$} & \multirow{2}{*}{$\begin{array}{c}\text { Liquid-to-Solid } \\
\text { Ratio } \\
\text { (ml/g) } \\
\end{array}$} & \multirow{2}{*}{$\begin{array}{c}\text { Contact Time } \\
\text { (hours) }\end{array}$} & \multirow{2}{*}{$\begin{array}{c}\text { Acid }^{\mathrm{b}} \\
(\mathrm{ml})\end{array}$} & \multicolumn{3}{|c|}{ Percent Material Dissolved } & \multirow{2}{*}{$\begin{array}{c}\text { Pu Concentration } \\
\text { in Leach Heel } \\
\text { (g Pu/g solid) }\end{array}$} \\
\hline & & & & & $\mathrm{Pu}$ & $\mathrm{Am}$ & Total Solids & \\
\hline 1 & chloride & $10: 1$ & 4 & 500 & 98.2 & 96.7 & 52.0 & $1.31 \times 10^{-3}$ \\
\hline 2 & chloride & $5: 1$ & 4 & 500 & 96.4 & 99.9 & 35.7 & $1.77 \times 10^{-3}$ \\
\hline 3 & chloride & $10: 3$ & 4 & 250 & 96.5 & 95.9 & 34.0 & $1.82 \times 10^{-3}$ \\
\hline 4 & chloride & $5: 2$ & 4 & 250 & 96.7 & 95.1 & 38.8 & $1.71 \times 10^{-3}$ \\
\hline 5 & chloride & $2: 1$ & 4 & 250 & 95.1 & 93.7 & 33.6 & $2.05 \times 10^{-3}$ \\
\hline 6 & nitric & $10: 1$ & 4 & 500 & 76.3 & 82.6 & 59.6 & $2.03 \times 10^{-2}$ \\
\hline 7 & nitric & $10: 1$ & 4 & 250 & 88.4 & 90.2 & 63.2 & $1.14 \times 10^{-2}$ \\
\hline 8 & nitric & $5: 1$ & 4 & 500 & 63.0 & 70.4 & 38.3 & $2.11 \times 10^{-2}$ \\
\hline 9 & nitric & $5: 1$ & 4 & 250 & 65.4 & 74.3 & 50.0 & $2.31 \times 10^{-2}$ \\
\hline 10 & nitric & 10.3 & 4 & 500 & 38.0 & 49.7 & 24.1 & $2.74 \times 10^{-2}$ \\
\hline 11 & nitric & $10: 3$ & 4 & 250 & 35.4 & 45.4 & 54.9 & $4.77 \times 10^{-2}$ \\
\hline 12 & nitric & $5: 2$ & 4 & 250 & 29.3 & 42.2 & 54.1 & $5.06 \times 10^{-2}$ \\
\hline 13 & nitric & $2: 1$ & 4 & 250 & 20.3 & 34.7 & 39.4 & $3.99 \times 10^{-2}$ \\
\hline 14 & chlorides. & $2: 1$ & 2 & 250 & 78.0 & 59.5 & 7.0 & $4.52 \times 10^{-3}$ \\
\hline 13 & chlorlde $e^{r}$ & $3: 1$ & 2 & 250 & 82.5 & 62.0 & $13 . n$ & $3.71 \times 10^{-3}$ \\
\hline
\end{tabular}

${ }^{9}$ The chloride leach system consists of $10 \mathrm{M} \mathrm{HCl}, 0.5 \mathrm{M} \mathrm{SnCl}_{2}$, and $0.1 M \mathrm{HF}$. The nitric leach system consists of $12.5 \mathrm{MHNO}_{3}$ and $0.2 M \mathrm{CaF}_{2}$.

${ }^{b}$ The $\mathrm{ml}(\mathrm{s})$ acid used was varied because in some of the runs using a low solid-to-liquid ratio, the ash-liquid mixture foamed over the top of the system and the run had to be rerun using a smaller volume.

${ }^{c}$ The leach solution as described in No. 1 except $0.2 M$ HF was used on these two runs.

\section{Leach Solution Concentration}

The effect of varying the composition of the hydrochloric acid leach solution on removal of plutonium and americium from incinerator ash is given in Table 2. While one of the components was varied, the remaining component concentrations were held at a nominal value for the first 14 runs. The nominal concentrations used were $10 \mathrm{M} \mathrm{HCl}, 0.5 \mathrm{M}$
$\mathrm{SnCl}_{2}$, and $0.1 M \mathrm{HF}$. The experiments included runs in which the fluoride ion concentration was varied from $0.0 M$ to $2.5 M$, the stannous chloride concentration was varied from $0.1 M$ to $2.5 M$, and the hydrochloric acid concentration was varied from $2.5 M$ to $10.0 M$. By observing the maximum recovery of plutonium as each of the component concentrations were varied independently; the following optimum reactant concentrations were found:

Table 2. Evaluation of Optimum Hydrofluoric Acid, Stannous Chloride and Hydrochloric Acid Concentration.

\begin{tabular}{cc} 
Run & $\begin{array}{c}\text { Liquid/Solid Ratio } \\
\text { (ml acid/g solid) }\end{array}$ \\
\cline { 2 - 2 } 1 & 10 \\
2 & 10 \\
3 & 10 \\
4 & 10 \\
5 & 10 \\
6 & 10 \\
7 & 10 \\
8 & 10 \\
9 & 10 \\
10 & 10 \\
11 & 10 \\
12 & 10 \\
13 & 2 \\
14 & 2 \\
15 & 2 \\
16 & 2 \\
17 & 2 \\
18 & 2 \\
19 & 2 \\
\end{tabular}

\begin{tabular}{|c|c|c|}
\hline HF & $\mathrm{SnCl}_{2}$ & $\mathrm{HCl}$ \\
\hline 0.1 & 0.5 & 10.0 \\
\hline 0.0 & 0.5 & 10.0 \\
\hline 0.5 & 0.5 & 10.0 \\
\hline 1.0 & 0.5 & 10.0 \\
\hline 2.5 & 0.5 & 10.0 \\
\hline 0.1 & 0.1 & 10.0 \\
\hline 0.1 & 1.25 & 10.0 \\
\hline 0.1 & 1.0 & 10.0 \\
\hline 0.1 & 2.5 & 10.0 \\
\hline 0.1 & 0.5 & 5.0 \\
\hline 0.1 & 0.5 & 7.5 \\
\hline 0.1 & 0.5 & 2.5 \\
\hline 0.1 & 0.5 & 10.0 \\
\hline 1.0 & 0.5 & 10.0 \\
\hline 1.0 & 0.1 & 10.0 \\
\hline 1.0 & 0.1 & 7.5 \\
\hline 0.25 & 0.1 & 10.0 \\
\hline 0.25 & 0.0 & 10.0 \\
\hline 0.25 & 0.0 & 7.5 \\
\hline
\end{tabular}

\begin{tabular}{|c|c|c|}
\hline $\mathrm{Pu}$ & Am & $\begin{array}{l}\text { Total } \\
\text { Solids }\end{array}$ \\
\hline 95.2 & 93.2 & 56.2 \\
\hline 98.2 & 95.8 & 56.6 \\
\hline 99.3 & 98.4 & 57.8 \\
\hline 99.3 & 97.6 & 59.2 \\
\hline 98.4 & 97.2 & 59.8 \\
\hline 99.3 & 98.4 & 67.2 \\
\hline 96.7 & 96.0 & 53.0 \\
\hline 98.4 & 96.7 & 46.2 \\
\hline 38.6 & 75.9 & 45.4 \\
\hline 98.7 & 97.6 & 30.2 \\
\hline 99.2 & 97.6 & 44.6 \\
\hline 68.1 & 73.3 & 23.4 \\
\hline 98.77 & 92.47 & 19.7 \\
\hline 98.91 & 91.93 & 19.5 \\
\hline 93.52 & 99.24 & 19.7 \\
\hline 97.91 & 96.46 & 16.2 \\
\hline 97.23 & 92.74 & 16.3 \\
\hline 93.20 & 92.53 & 16.1 \\
\hline 98.11 & 95.00 & 23.5 \\
\hline
\end{tabular}

\begin{tabular}{c}
$\begin{array}{c}\text { Pu Concentration } \\
\text { in Heel }\end{array}$ \\
(g Pu/g solid) \\
\hline $4.02 \times 10^{-3}$ \\
$1.66 \times 10^{-3}$ \\
$5.53 \times 10^{-4}$ \\
$5.04 \times 10^{-4}$ \\
$1.42 \times 10^{-3}$ \\
$7.37 \times 10^{-4}$ \\
$2.50 \times 10^{-3}$ \\
$1.07 \times 10^{-3}$ \\
$5.09 \times 10^{-2}$ \\
$6.65 \times 10^{-4}$ \\
$5.00 \times 10^{-4}$ \\
$1.51 \times 10^{-2}$ \\
$4.44 \times 10^{-4}$ \\
$4.39 \times 10^{-4}$ \\
$2.49 \times 10^{-3}$ \\
$7.72 \times 10^{-4}$ \\
$1.04 \times 10^{-3}$ \\
$2.70 \times 10^{-3}$ \\
$6.43 \times 10^{-4}$
\end{tabular}

Note: All runs were made using a reaction time of 2 hours. 


$$
\begin{aligned}
& \mathrm{HF} \\
& \mathrm{SnCl}_{2} \approx 0.5 M \\
& \mathrm{HCl}
\end{aligned}
$$

The interaction of varying two concentrations at the same time was also evaluated and the experimental results are presented in Runs 15 through 19. No improvement in plutonium and americium recoveries was obtained in these experiments when compared to the results obtained in the first 14 experiments. Of the 19 experiments summarized in Table 2, only two experiments failed to produce discard concentrations of plutonium in the leach heel.

\section{Residence Time}

Experiments were performed in both the nitric acid and the hydrochloric acid leaching systems to evaluate the effect of varying the residence time on the plutonium and americium removed from incinerator ash. Each residence-time run was a separate experiment and the recoveries are reported as the amount that is removed in the specified residence time.

Data obtained in these experimental runs are summarized in Table 3. Runs were made at 2:1 and 10:1 liquid-to-solid ratios ( $\mathrm{ml}$ solution/g solid) in both acid systems. In the hydrochloric acid system, and at both 2:1 and 10:1 liquidto-solid ratios, only minor variation in recoveries was observed in runs where the residence time was varied from 1 to 4 hours. In the nitric acid system at a $2: 1$ liquid-tosolid ratio, only minor variation in recovery was observed as a function of residence time. However, at the 10:1 liquid-to-solid ratio, increasing the residence time from 1 hour to 2 hours increased the plutonium recovery from 59 to $76 \%$. Increasing the residence time to 4 hours did not provide any further improvement in recovery. All experiments, using the hydrochloric acid system presented in Table 3, resulted in the plutonium concentration of the leach heel below the present discard limit. The leach heel from all of the nitric acid experiments were above the discard limit for this type of material.

\section{Multiple Contacts}

Experiments were performed to determine the effect of contacting one batch of ash with several batches of fresh hydrochloric acid solution. Table 4 contains the results of the multiple contact experiments. The percent plutonium removed in the first contact was 96.7. After four contacts with fresh acid, the accumulative percent plutonium removal was increased to 99.3. The efficiency (\% plutonium dissolved in each contact per the total plutonium entering that contact) per contact decreased from $96.7 \%$ for the first contact to $61.8,30.7$, and 21.2 for the second, third, and fourth contacts, respectively.

After the first contact, the plutonium concentration in the

\begin{tabular}{|c|c|c|c|c|c|c|c|c|}
\hline \multirow[b]{2}{*}{$\begin{array}{l}\text { Liquid-to-Solid } \\
\text { Ratio } \\
\text { (ml acid/g solid) }\end{array}$} & \multicolumn{8}{|c|}{$\begin{array}{l}\text { Hydrochloric Acid System } \\
\text { io } M \mathrm{HCl}, 0.5 M \mathrm{SnCl}_{2}, 0.1 M \mathrm{HF}\end{array}$} \\
\hline & $\begin{array}{c}\% \text { Pu } \\
\text { Removed }\end{array}$ & $\begin{array}{l}\text { \% Am } \\
\text { Removed }\end{array}$ & $\begin{array}{l}\% \text { Ash } \\
\text { Removed }\end{array}$ & $\begin{array}{l}\text { Leach Heel } \\
\text { Pu Conc. } \\
\text { (g Pu/g solid) }\end{array}$ & $\begin{array}{c}\% \mathrm{Pu} \\
\text { Removed }\end{array}$ & $\begin{array}{l}\text { \% Am } \\
\text { Removed }\end{array}$ & $\begin{array}{l}\% \text { Ash } \\
\text { Removed }\end{array}$ & $\begin{array}{c}\text { Leach Heel } \\
\text { Pu Conc. } \\
\text { (g Pu/g solid) }\end{array}$ \\
\hline $\begin{array}{l}\text { 1-hr Residence } \\
\text { Timt }\end{array}$ & 98.4 & 96.3 & 49.8 & $1.02 \times 10^{-3}$ & 95.5 & 92.7 & 18.2 & $1.73 \times 10^{-3}$ \\
\hline $\begin{array}{l}\text { 3-hr Residence } \\
\text { Time }\end{array}$ & 97.8 & 95.8 & 42.8 & $1.26 \times 10^{-3}$ & 97.2 & 95.0 & 18.1 & $8.27 \times 10^{-4}$ \\
\hline \multirow[t]{2}{*}{ 4-hr Residence } & 99.0 & 97.7 & 46.2 & $6.02 \times 10^{-4}$ & 94.1 & 93.4 & 19.8 & $2.21 \times 10^{-3}$ \\
\hline & \multicolumn{7}{|c|}{$\begin{array}{c}\text { Nitric Acid System } \\
\text { 12.5 } \mathrm{MHO}_{3}, 0.2 \mathrm{M} \mathrm{CaF}_{2}\end{array}$} & , \\
\hline $\begin{array}{l}\text { 3-hr Residence } \\
\text { Time }\end{array}$ & 76.0 & 81.6 & 49.0 & $1.70 \times 10^{-2}$ & 9.6 & 2.4 & 53.2 & $5.41 \times 10^{-2}$ \\
\hline $\begin{array}{l}\text { 4-hr Residence. } \\
\text { Time }\end{array}$ & 73.9 & 81.0 & 48.6 & $1.75 \times 10^{-2}$ & 7.9 & 3.6 & 38.0 & $5.44 \times 10^{2}$ \\
\hline
\end{tabular}
ash had been reduced to less than the present discard

Table 3. Evaluation of Optimum Residence Time. (Percent plutonium-americium and ash dissolved.) 
Table 4. Results of Multiple Contact Study Using Hydrochloric Acid Solution.

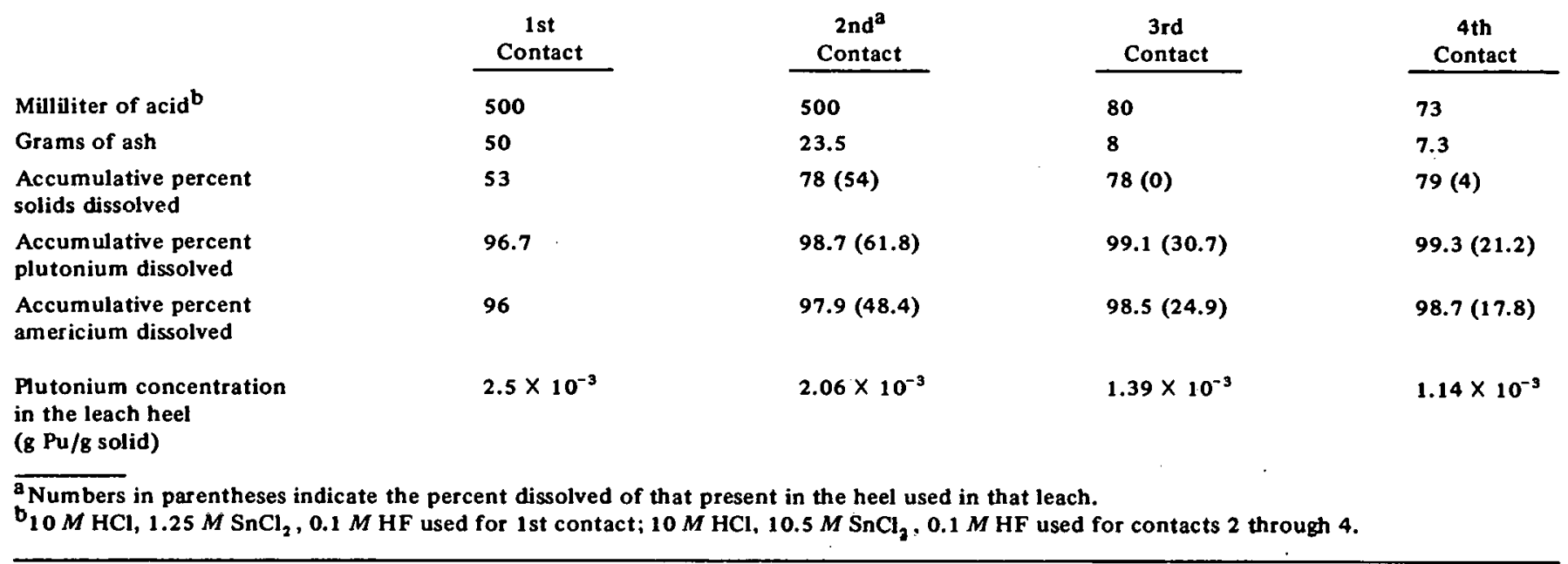

limits. However, three additional contacts failed to reduce the plutonium concentration to a tactor of 10 below the present discard limit.

One batch of No. 5 ash leach heel (incinerator ash which had been leached five times in the $\mathrm{HNO}_{3}-\mathrm{HF}$ production process) was contacted 10 times with fresh hydrochloric acid solution. A plot of the accumulative percent plutonium dissolved and the percent efficiency per contact is presented in Figure 1. Based on the plutonium analysis of the leach liquor, the efficiency per contact dropped from $70 \%$ for the first contact to $1 \%$ or less for each contact from the third through the tenth. Based on the leach liquor plutonium concentration, the accumulative plutonium recovered was only $75 \%$ after the 10 leaches. However, analysis of the leach heel indicated the accumulative recovery after 10 leaches was about $90 \%$. The leach heel after the first contact was $5.96 \times 10^{-3} \mathrm{~g} \mathrm{Pu} / \mathrm{g}$ solid (below present discard limit). The additional nine contacts produced a leach heel plutonium concentration $\left(2.24 \times 10^{-3}\right.$ $\mathrm{g} \mathrm{Pu} / \mathrm{g}$ solid) which was not a factor of 10 below the present discard limit.

\section{Alternate Acid-Base Treatment}

Presented in Table 5 are the results of several experiments performed to evaluate the effect of caustic leaching of incinerator ash prior to hydrochloric acid leaching for removal of the plutonium and americium. The objective of the caustic leach is to decrease the bulk volume and to expose the plutonium for the subsequent acid leach. The first two runs (Table 5) were performed to provide reference data for utilizing double contacts with fresh hydro. chloric acid. Comparison of Run 2 with Runs 3 and 4 indicates that a double hydrochloric acid leach will provide

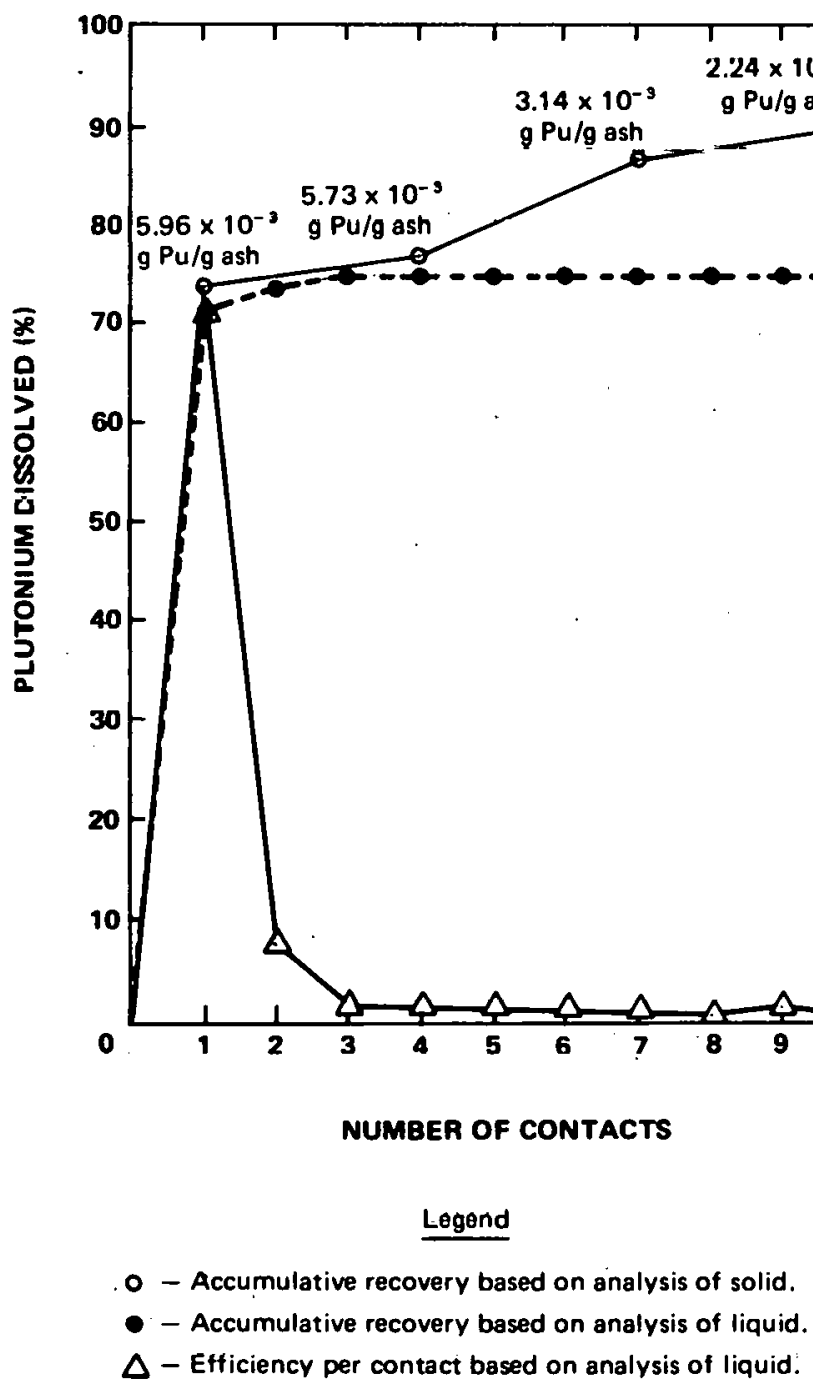

Figure 1. Multiple Contact Study - No. $5 \mathrm{Ash}$ Heel. $100 \mathrm{~g}$ ash, 2:1 ratio liquid to solid, 1 hour contacts, $10 \mathrm{M} \mathrm{HCl}$, $0.5 \mathrm{M} \mathrm{SnCl}_{3}, 0.1 \mathrm{MHF}, 2.10 \mathrm{~g} \mathrm{Pu}$ - X-ray-radioassay. 
Table 5. Amount of Material Dissolved by Contacting Virgin Incinerator Ash with Alternating Acid-Base Treatment.

\begin{tabular}{|c|c|c|c|c|c|c|c|}
\hline \multirow[b]{2}{*}{ Run } & \multirow[b]{2}{*}{ Leach $^{\mathbf{a}}$} & \multirow{2}{*}{$\begin{array}{l}\text { MQ Leach Solution } \\
\text { per Gram of Ash }\end{array}$} & \multirow{2}{*}{$\begin{array}{c}\text { Contact } \\
\text { Time } \\
\text { (hr) }\end{array}$} & \multicolumn{3}{|c|}{ Accumulative Percent Material Dissolved ${ }^{b}$} & \multirow{2}{*}{$\begin{array}{c}\text { Pu Conc. in } \\
\text { Heel } \\
\text { (g Pu/g solid) }\end{array}$} \\
\hline & & & & Plutonium & Americium & Total Solids & \\
\hline \multirow[t]{2}{*}{1} & Acid & 5 & 1 & 94.8 & 93.1 & 28.3 & $5.91 \times 10^{-4}$ \\
\hline & Acid (2nd contact) & 5 & 1 & $97.8(57.0)$ & $96.4(47.3)$ & $36.8(13.7)$ & $2.94 \times 1 \sigma^{4}$ \\
\hline \multirow[t]{2}{*}{2} & Acid & 2 & 1 & 97.2 & 91.0 & 12.1 & $7.72 \times 10^{-4}$ \\
\hline & Acid (2nd contact) & 2 & 4 & $99.1(69.2)$ & $96.5(61.6)$ & $21.6(10.8)$ & $2.67 \times 10^{-4}$ \\
\hline \multirow[t]{2}{*}{3} & Base & 5 & 2 & 0.03 & 0.11 & 28 & $4.37 \times 10^{-2}$ \\
\hline & Acid (2nd contact) & 5 & 4 & $99.5(99.5)$ & $96.5(96.5)$ & $53(33)$ & $4.12 \times 10^{-4}$ \\
\hline \multirow[t]{3}{*}{4} & Acid & 5 & 4 & 97.2 & 94.1 & 30 & $1.31 \times 10^{-3}$ \\
\hline & Base (2nd contact) & 5 & 2 & $97.3(4.6)$ & $94.3(3.5)$ & $81(72.5)$ & $4.63 \times 10^{-3}$ \\
\hline & Acid ( 3 rd contact) & 5 & 4 & $99.5(86.5)$ & $96.8(43.2)$ & $87(32.1)$ & $9.19 \times 10^{-4}$ \\
\hline
\end{tabular}

The acid leach is $10 \mathrm{M} \mathrm{HCl}, 0.5 \mathrm{MSnCl}_{2}, 0.1 \mathrm{MHF}$. The base leach is $10 \mathrm{M} \mathrm{NaOH}$.

${ }^{b}$ The number in parentheses indicates the percentage dissolved of that present in the heel used in that leach.

plutonium and americium recoveries as high as will be obtained utilizing the alternating acid-base treatments. The plutonium concentrations in the heel produced in all four runs were well below the present discard limit for incinerator ash. In Runs 1, 2, and 3, the heel plutonium concentration was a factor of 10 below the present discard limit. However, it should be pointed out that the use of caustic would necessitate decontamination of both an acid and a basic stream.

\section{Fusion Treatment}

- Tables 6 and 7 contain the results of fusion experiments using No. 5 ash leach heel. Run No. 1, Table 6, was a hydrochloric acid leach made for comparison purposes. Only two fusion experiments, Runs 1 and 3, Table 7, resulted in a plutonium recovery higher than that obtained with the hydrochloric acid leach (Run 1, Table 6). The fusion experiment (Run 1, Table 7), which utilized $3 \mathrm{~g}$ of
No. 5 ash heel, $6 \mathrm{~g} \mathrm{NaOH}$ and $1 \mathrm{~g} \mathrm{SnCl}_{2}$ resulted in a plutonium recovery of $98.98 \%$. A second run using the same conditions (Run 9, Table 7), resulted in a recovery of only $80.9 \%$.

Because the fusion method adds a significant amount of material to the ash (thereby generating a greater volume of waste) and because it is a high temperature process, it is far less desirable than a direct leaching of the ash unless a significant improvement can be made in plutonium recovery.

\section{Fluorination Pretreatment}

Both incinerator ash and No. 5 ash leach heel were subjected to fluorination prior to nitric acid-aluminum nitrate leaching to determine if the recovery of plutonium could be increased. The fluorination was accomplished by passing fluorine over a boat of ash at about $300^{\circ} \mathrm{C}$ for about one

Toble 6. Pesults of Fusion Tests with No. 5 Leach Hoel.

\begin{tabular}{|c|c|c|c|c|c|c|c|c|c|}
\hline \multirow[b]{2}{*}{ Run } & \multirow{2}{*}{$\begin{array}{c}\text { Wt of No. } 5 \text { Ash } \\
\text { Leach Heel } \\
\text { (g) }\end{array}$} & \multirow{2}{*}{$\begin{array}{l}\text { Wt of Fusion } \\
\text { Medià } \\
\text { (g) }\end{array}$} & \multirow{2}{*}{$\begin{array}{c}\text { Fusion } \\
\text { Temp. } \\
\text { (C) }\end{array}$} & \multirow{2}{*}{$\begin{array}{l}\text { Vol. Leach } \\
\text { Solution } \\
\text { (ml) }\end{array}$} & \multicolumn{4}{|c|}{$\begin{array}{c}\text { Leach Solution } \\
\text { Composition }\end{array}$} & \multirow{2}{*}{$\begin{array}{l}\text { Percent Pu } \\
\text { Recovered }\end{array}$} \\
\hline & & & & & $\mathrm{HCl}$ & $\mathrm{Sn}^{+1}$ & $F^{-}$ & $\mathrm{AlCl}_{3}$ & \\
\hline 1 & 3 & 0 & - & 30 & $10 N$ & $0.5 N$ & $0.1 N$ & - & 82.56 \\
\hline 2 & 3 & 3-LiF & 880 & 30 & $10 N$ & - & - & $3.7 M$ & 21.54 \\
\hline 3 & 3 & 3-NaF & 880 & 30 & $10 N$ & - & - & $3.7 M$ & 67.86 \\
\hline 4 & 3 & $3 \cdot \mathrm{KF}$ & 880 & 30 & $10 N$ & - & - & $3.7 M$ & 22,56 \\
\hline 5 & 3 & $6-K F \cdot H F$ & 800 & 50 & $10 N$ & U.sN & $\dot{0} .1 N$ & - & 65.13 \\
\hline 6 & 3 & $\begin{array}{l}\text { 2-Evap Salts, } \\
\text { 6- } \mathrm{NaOH}\end{array}$ & 500 & 30 & $10 N$ & - & - & $3.7 M$ & 74.70 \\
\hline 7 & 3 & $\begin{array}{l}3-\mathrm{AlCl}_{3} \\
3-\mathrm{NaCl}\end{array}$ & 800 & 30 & $10 N$ & $0.5 N$ & $0.1 N$ & - & 46.84 \\
\hline 8 & 3 & $\begin{array}{l}\text { 1-Evap Salts } \\
4-\mathrm{NaOH} \\
\text { 1-KF } \mathrm{HF}\end{array}$ & 500 & 30 & $10 N$ & - & - & $3.7 M$ & 26.15 \\
\hline
\end{tabular}

\footnotetext{
-2-hour contact time.
} 
RFP-1723

Table 7. Results of Fusion Tests with No. 5 Ash Leach Heels.

\begin{tabular}{|c|c|c|c|c|c|c|}
\hline Run & $\begin{array}{c}\text { Wt of No. } 5 \text { Ash } \\
\text { Leach Heel } \\
\text { (g) }\end{array}$ & $\begin{array}{c}\text { Wt of Fusion } \\
\text { Media } \\
(\mathrm{g})\end{array}$ & $\begin{array}{c}\text { Fusion } \\
\text { Temp. } \\
\text { ( C) } \\
\end{array}$ & $\begin{array}{l}\text { Vol. Leach } \\
\text { Solution } \\
(\mathrm{ml}) \\
\end{array}$ & $\begin{array}{c}\begin{array}{c}\text { Leach } \\
\text { Solution }^{\mathrm{a}}\end{array} \\
\end{array}$ & $\begin{array}{l}\text { Accumulative Pcrcent } \\
\text { Plutonium Recovered } \\
\end{array}$ \\
\hline 1 & 3 & $\begin{array}{l}6 \mathrm{NaOHI} \\
1 \mathrm{SnCl}_{2}\end{array}$ & 450 & 30 & $\mathrm{H}_{2} \mathrm{O}$ & 2.38 \\
\hline 2nd contact & - & - & - & 30 & $\mathrm{HCl}$ & $98.98(96.58)$ \\
\hline 2 & 3 & $\begin{array}{l}6 \mathrm{NaOH} \\
1 \mathrm{SnCl}_{2}\end{array}$ & 450 & 60 & $\mathrm{H}_{2} \mathrm{O}$ & 1.94 \\
\hline 2nd contact & - & - & - & 60 & $\mathrm{HCl}$ & $80.90(78.04)$ \\
\hline 3 & 3 & $\begin{array}{l}6 \mathrm{NaOH} \\
2 \mathrm{SnCl}_{2}\end{array}$ & 450 & 60 & $\mathrm{H}_{2} \mathrm{O}$ & 1.33 \\
\hline 2nd contact & - & - & - & 60 & $\mathrm{HCl}$ & $90.19(88.86)$ \\
\hline 4 & 3 & $\begin{array}{l}6 \mathrm{NaOH} \\
1 \mathrm{SnCl}_{2} \\
1 \mathrm{KF}\end{array}$ & 450 & 30 & $\mathrm{H}_{2} \mathrm{O}$ & 8.38 \\
\hline 2nd contact & - & - & - & 30 & $\mathrm{HCl}$ & $22.07(13.69)$ \\
\hline 5 & 3 & $6 \mathrm{NaOH}$ & 450 & 30 & $\mathrm{H}_{2} \mathrm{O}$ & 4.26 \\
\hline 2nd contact & - & - & - & 30 & $\mathrm{HCl}$ & $56.23(51.97)$ \\
\hline 6 & 3 & $\begin{array}{l}6 \mathrm{NaOH} \\
i \mathrm{KF}\end{array}$ & 450 & 30 & $\mathrm{H}_{2} \mathrm{O}$ & 4.89 \\
\hline 2nd contact & - & - & - & 30 & $\mathrm{HCl}$ & $50.07(45.81)$ \\
\hline 7 & 3 & $6 \mathrm{~K}_{2} \mathrm{~S}_{3} \mathrm{O}_{7}$ & 850 & 30 & $\mathrm{HCl}$ & 50.09 \\
\hline 8 & 3 & $9 \mathrm{~K}_{2} \mathrm{~S}_{2} \mathrm{O}_{7}$ & 850 & 30 & $\mathrm{HCl}$ & 52.65 \\
\hline 9 & 3 & $12 \mathrm{~K}_{2} \mathrm{~S}_{2} \mathrm{O}_{7}$ & 850 & 30 & $\mathrm{HCl}$ & 61.54 \\
\hline 10 & 3 & $15 \mathrm{~K}_{2} \mathrm{~S}_{2} \mathrm{O}_{7}$ & 850 & 30 & $\mathrm{HCl}$ & 14.94 \\
\hline
\end{tabular}

The hydrochloric acid is $10 M \mathrm{HICl}, 0.5 M \mathrm{Sn}^{++}, 0.1 \mathrm{MF}^{-}$.

balue in parentheses is the percentage of the original plutonium in the ash which is dissolved by that leach.

hour. Aluminum was added to the leach solution to com. plex free fluoride ion and therefore shift the equilibrium to a more favorable dissolution. Table 8 contains the results of these experiments. Some of the samples were leached in hydrochloric acid or nitric acid prior to the fluorination. Runs 1 and 2 indicate that recovery of about $90 \%$ could be expected by nitric acid-aluminum nitrate leaching of No. 5 ash leach heel which has been fluorinated. This compares favorably with nonfluorinated samples (Run 14 and 15, Table 1) where the recovery of plutonium was about $80 \%$ using a hydrochloric acid leach.

Plutonium recoveries of 77.6 and $82.5 \%$ were obtained on the first contact of No. 5 ash leach heel with hydrochloric acid (Runs 3 and 5, Table 8). When these two samples were fluorinated and given a contact with nitric acid-aluminum nitrate solution, recoveries of 67.7 and 97.35 were obtained in the leaches. This indicates that a fluorination treatment prior to a second leach using nitric acid-aluminum nitrate will greatly improve the efficiency of the second leach; as for example, when No. 5 ash leach heel was subjected to multiple contact.with fresh acid (Figure 1), plutonium recoveries of $71 \%$ and $8 \%$ were obtained for the first and second contacts, respectively. Two out of the four heels produced from No. 5 ash leach heel were a factor of 10 below the present discard plutonium concentration limit. The one sample of incinerator ash (Run 4, Table 8) which was leached in nitric acid solution, fluorinated, and leached in nitric acid-aluminum nitrate produced a discard plutonium concentration in the heel.

One advantage of the fluorination and the nitric acidaluminum nitrate leaching is that the plutonium would be recovered in a nitric acid system which would be compatible with the present production recovery process. When the plutonium is leached in to a hydrochloric acid system, it will have to be precipitated and redissolved in nitric acid for purification by anion exchange.

It should be pointed out that these results are only preliminary and more data will have to be obtained to confirm these results. 
RFP-1723

Table 8. Results of Experiments Utilizing Fluorinotion Treatment Prior to a Nitric Acid-Aluminum Nitrate Leach.

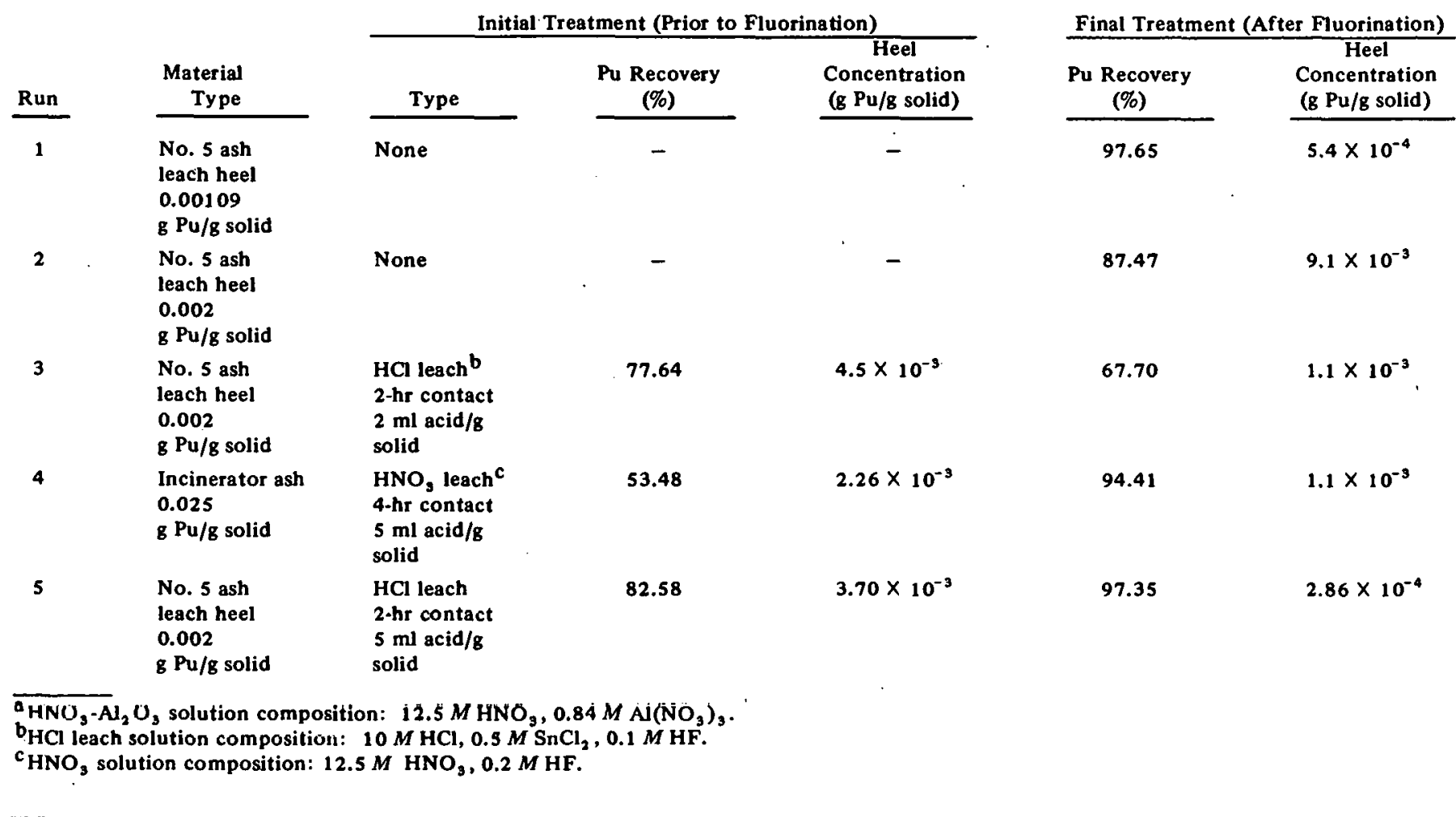

\section{Recovery of Plutonium and Americium from Hydrochloric Acid Leach Solution}

If hydrochloric acid is used to remove plutonium and americium from incinerator ash or ash leach heels, it. will be necessary to have a method of removing plutonium and americium from the acid so that they can be returned to the nitric acid system for purification and conversion.to metal. Preliminary evaluations were made of three precipitation methods; oxalate, fluoride, and hydroxide. Each test was made using 3.36 gram per liter plutonium in a $5 \mathrm{M} \mathrm{HCl}$ solution obtained from the leach studies on incinerator ash.

For the oxalate precipitation, the normality of the acid was first adjusted to 0.5 by the addition of $10 \mathrm{~N} \mathrm{NaOH}$ with an approximate $50 \%$ increase in volume. The precipitation was made using oxalate at $5 \%$ excess of the stoichiometric amount. The solution after precipitation analyzed $9.8 \times 10^{-2}$ grams plutonium per liter, which corresponds to a $95.6 \%$ removal. A small amount of $\mathrm{MgCl}_{2}$ was added in an attempt to carry down more plutonium with magnesium oxalate precipitate. This method removed about half of the remaining plutonium, resulting in a solution containing $3.9 \times 10^{-2}$ grams plutonium per liter. This precipitation method would appear to be unsatisfactory because of its low efficiency.

For the fluoride precipitation, the solution was made $0.5 \mathrm{~N}$ acid by addition of $10 \mathrm{~N} \mathrm{NaOH}$, with the accompanying $50 \%$ increase in volume. Additions of hydrofluoric acid to make the solution $2 M \mathrm{HF}$ resulted in the supernatant solution, which analyzed $1.4 \times 10^{-3}$ grams plutonium per liter. This is equivalent to a removal of $99.94 \%$ of the plutonium in solution. A second and third precipitation was made using $0.5 \mathrm{M} \mathrm{La}^{3+}$ as a carrier, resulting in supernatant solutions analyzing $5.4 \times 10^{-4}$ and $3.2 \times 10^{-4}$ grams plutonium per liter, respectively. This precipitation method will probably be satisfactory for over-all recovery requiremenț.

For the hydroxide precipitation, the acid was adjusted to pH of 12 using $10 \mathrm{~N} \mathrm{NaOH}$ with a volume increase of about $50 \%$. The supernatant solution, after removal of the precipitate, analyzed $7.4 \times 10^{-5}$ grams plutonium per liter.

A second and third precipitation of supernatant solution was made using $0.5 \mathrm{M} \mathrm{Mg}^{2+}$ as a carrier, resulting in supernatant solutions analyzing $2.9 \times 10^{-5}$ and $3.8 \times 10^{-5}$ grams plutonium per liter, respectively. This method appears to provide 


\section{RFP-1723}

a satisfactory recovery $(>99.99 \%)$ for over-all process considerations. The disadvantage of this method is that very little purification is obtained by precipitation. This means that the $\mathrm{HCl}$ leach and hydroxide precipitation would only serve to convert the plutonium into an insoluble form with essentially no purification. In an attempt to decrease the impurities in the hydroxide precipitate the solution was treated with formic acid, which would allow the soluble formates to be removed from the precipitate. However, the solubility of the plutonium formate was too great, resulting in excessive plutonium losses.

Either the fluoride precipitation method or the hydroxide precipitation method appears to provide a satisfactory method for removal of plutonium from the hydrochloric acid leach solution. The fluoride precipitation method is probably preferable because of the purification or selectivity of plutonium from the other impurities.

\section{REFERENCES}

1. G. F. Molen and R. O. Wing, "Dissolution of Plutonium-Bearing Residues in a Nitric Acid-Calcium Fluoride Solvent Systcm," USAEC RFP-766 (1966).

2. F. E. Butler, J. D. Moseley, and G. F. Molen, "Recovery of Plutonium from Incinerator Ash," USAEC RFP-396 (1964).

3. D. Crossley and G. W. C. Milner, "The Dissolution of Plutonium Dioxide in Hydrochloric Acid at High Temperature and Pressure," AERE-R6217 (1969).

4. G. F. Molen, "Dissolution of Plutonium Oxide," USAEC RFP-922 (1967). 